\title{
Research on the typical mechanical configuration scheme of the whole mechanical construction of overhead transmission lines in plain area
}

\author{
TANG Guang Rui ${ }^{1, a}$, JIANG Ming ${ }^{2, b}$, LIU Chen ${ }^{3, c}$, ZHOU Ya Ao ${ }^{4, d}$, MA Yong ${ }^{5, e}$ \\ ${ }^{1-4}$ China Electric Power Research Institute, Beijing, 100055, China \\ ${ }^{5}$ School of Mechanical Engineering, USTB, 100083, China \\ asatater227@163.com, biamjiangmings@126.com, \\ 'Ic901013@sina.com, 'wordsworthao@sina.com, ${ }^{\mathrm{e}}$ iammayongs@126.com
}

Keywords: plain area, transmission lines, mechanical construction, machinery allocation

\begin{abstract}
With the development of economy and technology, the new technology, new methods and new equipment are used in the construction of overhead transmission line. Currently, the part of the construction organizations lack cognition to this kind of new technology and new methods. Instead of, they rely more on experience to allocate construction equipment arbitrarily, which lead to the less use of the new technology and new equipment. At the same time, the construction organizations are lack of effective and standardized construction machinery allocation scheme of. overhead transmission lines. Plain area is a suitable terrain for the implementation of whole process mechanization because the open terrain is suitable for transitions of large-scale machinery and equipment. What's more, large area of road and bridge and it has high construction efficiency, low cost and obvious effect. This paper has researched on the typical mechanical configuration scheme of the whole mechanical construction of overhead transmission lines in plain area, which including seven processes.
\end{abstract}

\section{Introduction}

With the development of economy and technology, the new technology, new methods and new equipment are used in the construction of overhead transmission line. Currently, the part of the construction organizations lack cognition to this kind of new technology and new methods. Instead of, they rely more on experience to allocate construction equipment arbitrarily, which lead to the less use of the new technology and new equipment. At the same time, the construction organizations are lack of effective and standardized construction machinery allocation scheme of. overhead transmission lines. Plain area is a suitable terrain for the implementation of whole process mechanization. The configuration of the mechanical construction scheme can improve the construction efficiency and reduce the cost [1-5].

The whole mechanical construction of overhead transmission lines has seven processes, including temporary road construction, material transportation, excavation concrete pouring, tower group, guide wire erection and ground laying. This paper will put the plain area as a research object to explore the typical mechanical configuration program.

\section{Schemes of machinery allocation}

Temporary road construction. According to characteristics of the mechanical construction, temporary road construction is the premise of achieving the whole process of mechanical construction and all construction tower and temporary roads should be done before the completion of the construction. The trend of temporary road construction for every construction tower should be investigated and planned before the repairing of temporary road.

Equipment Organization: the specialized construction team should be established, a professional team to implement the management of the use of equipment. Construction equipment should be selected and assembled according to the period of project construction, conditions of the road and the specific road construction equipment is shown in table 1 : 
Table 1 Statistics of road construction equipment

\begin{tabular}{ccccccc}
\hline No. & $\begin{array}{c}\text { Construction } \\
\text { procedure }\end{array}$ & $\begin{array}{c}\text { Construction } \\
\text { equipment }\end{array}$ & models & number & $\begin{array}{c}\text { Scope of } \\
\text { application }\end{array}$ & Applicable geology \\
\hline 1 & & $\begin{array}{c}\text { excavating } \\
\text { machinery }\end{array}$ & $0.25 \sim 1.6 \mathrm{~m}^{3}$ & 1 & $\begin{array}{c}\text { Full voltage } \\
\text { level } \\
\text { Full voltage } \\
\text { level }\end{array}$ & Ordinary soil, sand \\
2 & $\begin{array}{c}\text { Road } \\
\text { Construction }\end{array}$ & $\begin{array}{c}\text { Bulldozer } \\
\text { Multifunctional }\end{array}$ & $\begin{array}{c}2.02 \sim 10 \mathrm{~m}^{3} \\
\text { Excavate: } \\
0.2 \mathrm{~m}^{3}\end{array}$ & 1 & $\begin{array}{c}\text { Full voltage } \\
\text { level }\end{array}$ & Ordinary soil, sand \\
4 & $\begin{array}{c}\text { Load: } 1 \mathrm{~m}^{3} \\
\text { roanstruction } \\
\text { equipment }\end{array}$ & 1 & $\begin{array}{c}\text { Full voltage } \\
\text { level }\end{array}$ & Whole geological \\
\hline
\end{tabular}

Material transportation. Material transport of line construction involves cement, sand, tower materials and other construction equipment, etc. Material handling will be done by tyre crane, the type of which is selected according to the weight and the working radius. Material transport equipment are including tire type transport vehicles and agricultural transport vehicles (or light trucks). Light trucks are recommended to transport a small amount of materials, light tower material and Derrick and the type of light truck based on the choice of the material length and the load. Transportation of steel reinforcement cage and isometric pole material use wheeled transport vehicle, while transportation of heavy material such as tying of tower materials, tension and other heavy equipment usually use $5 \mathrm{t} \sim 12 \mathrm{t}$ motor transport.

Teams and groups of material transport construction need 1 farm transport vehicles (or light trucks) and 1 tire type transport vehicles. Moreover, the center of the material station need one $5 t \sim 12 t$ car and 25t crane. The statistics of material transportation equipment are shown in table 2.

Table 2 Statistics of material transportation equipment

\begin{tabular}{|c|c|c|c|c|c|}
\hline No. & $\begin{array}{l}\text { Construction } \\
\text { procedure }\end{array}$ & $\begin{array}{l}\text { Construction } \\
\text { equipment }\end{array}$ & Models & number & Scope of application \\
\hline 1 & & $\begin{array}{l}\text { Wheeled transport } \\
\text { vehicle }\end{array}$ & $1.5 t / 2.5 t$ & 1 & $\begin{array}{l}\text { Long haul of full voltage } \\
\text { component }\end{array}$ \\
\hline 2 & & Flat Trailer & & 1 & $\begin{array}{l}\text { Transportation equipment of } \\
\text { rotary drilling rig and others }\end{array}$ \\
\hline 3 & $\begin{array}{l}\text { Material } \\
\text { transportation }\end{array}$ & $\begin{array}{l}\text { Light truck, } \\
\text { agricultural vehicle }\end{array}$ & Under $5 t$ & 6 & $\begin{array}{l}\text { Transportation of light material } \\
\text { in full voltage }\end{array}$ \\
\hline 4 & & automobile & $5 \sim 12 t$ & 2 & $\begin{array}{l}\text { Transportation of heavy } \\
\text { material and equipment }\end{array}$ \\
\hline 5 & & crane & $25 t$ & & Full grades \\
\hline
\end{tabular}

Drilling holes in the foundation. The types of foundation in lines are varied, and the machinery and equipment applicable to each type of foundation are not at the same. The pile foundation recommended using rotary digging machine into the hole. Light, medium or comprehensive of rotary drilling are used according to the geology and diameter and depth of the base holes. The foundation pit use excavator and the choice of excavators are selected according to the depth of the foundation pit. Mud puddles and pit excavation foundation use auxiliary drainage device to reduce groundwater level. The type and quantity of submersible pump, water pump and light well point device are determined according to the calculation of foundation pit water inflow. The filling pile foundation is provided with mature construction technology, which can be formed into a hole in the ground water rich or in the sand flow, and the submersible drilling machine or the rotary drilling rig can be selected according to the hole diameter. Statistics of mechanical equipment about typical pit hole forming and its adaptation are shown in table 3. 
Table 3 statistical table of basic mechanical equipment

\begin{tabular}{|c|c|c|c|c|c|c|}
\hline No. & $\begin{array}{c}\text { Construction } \\
\text { procedure }\end{array}$ & $\begin{array}{c}\text { Construction } \\
\text { equipment }\end{array}$ & Models & number & $\begin{array}{c}\text { Scope of } \\
\text { application }\end{array}$ & Applicable geology \\
\hline 1 & & rotary drilling rig & light & & $\begin{array}{c}\text { The diameter of } \\
\text { the pile and pile } \\
\text { foundation under } \\
1.4 \mathrm{~m}\end{array}$ & $\begin{array}{l}\text { Ordinary soil, } \\
\text { sand, mud pit }\end{array}$ \\
\hline 2 & & rotary drilling rig & $\begin{array}{c}\text { Medium } \\
\text { - } \\
\text { sized }\end{array}$ & 1 & $\begin{array}{c}\text { The diameter of } \\
\text { the pile and pile } \\
\text { foundation under } \\
1.4 \mathrm{~m}\end{array}$ & $\begin{array}{c}\text { Ordinary soil, } \\
\text { sand, mud pit, rock }\end{array}$ \\
\hline 3 & & rotary drilling rig & $\begin{array}{l}\text { Compre } \\
\text { hensive } \\
\text { type }\end{array}$ & & $\begin{array}{l}\text { The diameter of } \\
\text { the pile and pile } \\
\text { foundation under } \\
\text { 2m }\end{array}$ & $\begin{array}{c}\text { Ordinary soil, } \\
\text { sand, mud pit, rock }\end{array}$ \\
\hline 4 & & $\begin{array}{l}\text { Rotary drilling } \\
\text { rig }\end{array}$ & $\begin{array}{c}\text { aperture } \\
0.8 \sim 1.5 \\
\text { m }\end{array}$ & 1 & Flowing silt layer & Filling pile hole \\
\hline 5 & & $\begin{array}{l}\text { Special digging } \\
\text { machine for large } \\
\text { excavation }\end{array}$ & $\begin{array}{l}\text { JYM-17 } \\
00\end{array}$ & 1 & Full scale & Ordinary soil, sand \\
\hline 6 & $\begin{array}{l}\text { Hole forming } \\
\text { of foundation } \\
\text { pit }\end{array}$ & $\begin{array}{l}\text { Submersible } \\
\text { drilling rig }\end{array}$ & $\begin{array}{c}\text { aperture } \\
0.55 \sim 2.5 \\
\mathrm{~m}\end{array}$ & 1 & $\begin{array}{l}\text { High ground } \\
\text { water soft } \\
\text { foundation } \\
\text { geology }\end{array}$ & Filling pile hole \\
\hline 7 & & $\begin{array}{l}\text { Punching pile } \\
\text { driver }\end{array}$ & $\begin{array}{c}\text { aperture } \\
0.6 \sim 2.5 \\
\text { m }\end{array}$ & 1 & $\begin{array}{l}0.6 \sim 2.5 \mathrm{~m} \text { pile } \\
\text { diameter deep } \\
\text { foundation pile }\end{array}$ & $\begin{array}{l}\text { The soil, gravel, } \\
\text { boulders and rock } \\
\text { layer }\end{array}$ \\
\hline 8 & & $\begin{array}{l}\text { Grab drilling } \\
\text { machine }\end{array}$ & $\begin{array}{c}\text { aperture } \\
0.9 \sim 1.2 \\
\text { m }\end{array}$ & 1 & $\begin{array}{c}0.8 \sim 1.2 \mathrm{~m} \text { pile } \\
\text { diameter, pile } \\
\text { depth below } 50 \mathrm{~m} \\
\text { bored piles }\end{array}$ & $\begin{array}{l}\text { Silty clay, sand, } \\
\text { clay, strong } \\
\text { weathered rock }\end{array}$ \\
\hline 9 & & Spiral drill & $\begin{array}{l}\text { aperture } \\
0.4 \sim 1 \mathrm{~m}\end{array}$ & 1 & $\begin{array}{l}\text { Pile diameter is } \\
\text { not greater than } \\
1 \mathrm{~m} \text { perfusion } \\
\text { stake }\end{array}$ & $\begin{array}{c}\text { Cohesive soil, silt, } \\
\text { medium density } \\
\text { backfill }\end{array}$ \\
\hline 10 & & $\begin{array}{l}\text { Auxiliary } \\
\text { precipitation } \\
\text { equipment }\end{array}$ & $\begin{array}{c}\text { aperture } \\
72 \sim 800 \\
\text { m3/h、 } \\
\text { submerg } \\
\text { ed pump } \\
8 \sim 20 \mathrm{~m} 3 / \\
\mathrm{h}\end{array}$ & many & $\begin{array}{l}\text { Large excavation } \\
\text { foundation } \\
\text { precipitation }\end{array}$ & $\begin{array}{l}\text { Higher ground } \\
\text { water area }\end{array}$ \\
\hline
\end{tabular}

Concrete pouring. Commodity concrete is recommended in the plain area. If the commodity concrete is far away from the tower or around the tower, the concrete mixing station can be set up in the vicinity of the line, which can effectively reduce the area , the energy saving and emission reduction. Mixing station needs to be chosen according to production. It is necessary to accurately control the mixing ratio and improve the quality of concrete. Statistic table for typical concrete construction equipment is shown in Table 4.

Transportation of pre mixed concrete uses tank type transport vehicles, models can be selected based on demand for concrete volume and the choice of road capacity. The casting in the plain area can avoid setting the concrete pump pipe and concrete pump will transport concrete along the transmission pipeline, which not only reducing the workload of the erection and construction workers for pouring the foundation, but also conducive to the realization of the mechanization construction. When using the concrete pump truck, the working radius of the material should be considered. 
Vibrating device refers to using vibration tamping rod to compact concrete, which making concrete more dense, increased the intensity of the concrete and eliminate the phenomenon of concrete surface of the honeycomb. The more dry the concrete, the higher frequency of the vibrating rod is selected.

Table 4 concrete construction equipment configuration table

\begin{tabular}{cccccc}
\hline No & $\begin{array}{c}\text { construction } \\
\text { procedure }\end{array}$ & Construction equipment & Models & number & Scope of application \\
\hline 1 & & concrete batching plant & HJB25-HJB50 & 1 & Concentrated concrete mixing \\
2 & & Concrete pump truck & $65 \sim 180 \mathrm{~m}^{3}$ & 1 & Premixed concrete pumping \\
3 & & Concrete transportation & $2.2 \sim 5.5 \mathrm{~m}^{3}$ & 4 & Pre mixed concrete transportation \\
4 & concrete & Self falling mixer & $\mathrm{JBC} 350$ & 2 & Field mixing concrete \\
5 & construction & Concrete pump & $25 \sim 60 \mathrm{~m}^{3}$ & 1 & Premixed concrete pumping \\
6 & & Forced mixer & $25 \sim 40 \mathrm{~m}^{3} / \mathrm{h}$ & 3 & Field mixing concrete \\
7 & Vibrating spear & HZD25-69 & 8 & Full scale \\
\hline
\end{tabular}

Tower assembly. Plain area traffic is convenient. Tower building is recommended the tower crane. In order to improve the utilization rate of equipment and reduce the construction cost, different types of crane can be used. Small crane from bottom to top can be used from heavy to light lifting group. When the crane is not satisfied with the use of a large crane, the large crane can be replaced. Crane models can be determined according to the lifting weight and working radius.

In the plain areas, when there is a crane rental difficult and other objective factors, holding rod tower can be used according to the tower's shout, the hanging weight. Statistics about equipment for vertical tower group is shown in Table 5.

Table 5 Statistics about equipment for vertical tower group

\begin{tabular}{|c|c|c|c|c|}
\hline No. & $\begin{array}{l}\text { construction } \\
\text { procedure }\end{array}$ & Pole type & Models & topographic features \\
\hline 1 & & $\begin{array}{l}\text { Suspended external } \\
\text { pull pole }\end{array}$ & $\begin{array}{c}\text { ZBX-W- } 22.5 \times 500 \times 2.5 \sim Z B X- \\
W-42 \times 900 \times 9\end{array}$ & $\begin{array}{l}\text { Open terrain, cable is not } \\
\text { limited }\end{array}$ \\
\hline 2 & $\begin{array}{l}\text { Tower } \\
\text { assembly }\end{array}$ & $\begin{array}{l}\text { Single arm hold } \\
\text { Double arm hold }\end{array}$ & $\begin{array}{c}\text { ZBL-DY-50、ZBL-DY-160、 } \\
\text { ZBL-2P-25/10 ZBL-2P-24/8 }\end{array}$ & UHV steel tower, steel tower \\
\hline 3 & & crane & $16 t \sim 240 t$ & Flat ground \\
\hline
\end{tabular}

Ground wire erection. The ground wires are set up mainly including the guide line, the tight line and the accessories installation. In the development of the primary wire rope, it is recommended to use multi rotor UAV or power parachute. The transition for primary rope to guide rope adopts a miniature tension machine and a mini traction machine. The guide rope is used to convert the traction rope with a small tractor and a small tension machine. Traction rope to traction guide wire is recommended to use the traction machine and a traction two tension machine (one pull four) tension machine. One traction machine will be set in each line segment and release two wires to configure a two tension machine. Releasing four sub-lines need one 4 tension machine or two 1 and 2 tension machine.

Types of traction machine, tension machine, all levels of the guide wire, line tackle, out of tune, rotary joint, bending connector and other equipment are selected based on the ultra HV overhead transmission line tension stringing construction technology guide for calculating and determined about ultra high voltage line, based on the $800 \mathrm{kV}$ overhead transmission line tension stringing construction technology guide about EHV, the $1000 \mathrm{kV}$ overhead send electric line tension stringing construction technology guide for calculation. Equipment specification models and the corresponding string need to match. 
Table 6 statistical table for equipment to set up

\begin{tabular}{|c|c|c|c|c|c|}
\hline No & $\begin{array}{l}\text { construction } \\
\text { procedure }\end{array}$ & $\begin{array}{l}\text { Construction } \\
\text { equipment }\end{array}$ & Models & number & Scope of application \\
\hline 1 & \multirow{14}{*}{$\begin{array}{l}\text { Ground wire } \\
\text { erection }\end{array}$} & $\begin{array}{l}\text { Mini tension } \\
\text { machine }\end{array}$ & $0.2 \mathrm{t}$ & 1 & at all levels \\
\hline 2 & & Miniature tractor & $1 \mathrm{t}$ & 1 & at all levels \\
\hline 3 & & Small tractor & \multirow{4}{*}{ By calculation } & 1 & at all levels \\
\hline 4 & & $\begin{array}{l}\text { Small tension } \\
\text { machine }\end{array}$ & & 1 & at all levels \\
\hline 5 & & Tension machine & & 2 & at all levels \\
\hline 6 & & $\begin{array}{l}\text { The traction } \\
\text { machine }\end{array}$ & & 1 & at all levels \\
\hline 7 & & Spanning frame & l & 3 & at all levels \\
\hline 8 & & Multi rotor UAV & load 7kg & 1 & at all levels \\
\hline 9 & & $\begin{array}{l}\text { Powered } \\
\text { parachutes }\end{array}$ & $\begin{array}{l}\text { SQS-70 } \\
\text { SQS-340 }\end{array}$ & 1 & at all levels \\
\hline 10 & & $\begin{array}{l}\text { Hydraulic pump } \\
\text { station }\end{array}$ & $100 \mathrm{t} \sim 300 \mathrm{t}$ & 4 & at all levels \\
\hline 11 & & $\begin{array}{l}\text { Double roller } \\
\text { motor }\end{array}$ & $3 t, 5 t, 8 t$ & 4 & at all levels \\
\hline 12 & & aerodyne & $\begin{array}{c}\text { SFC- } 1 \times 400 、 \text { SFC- } 2 \times 400 \text { 、 } \\
\text { SFC- } 4 \times 400 、\end{array}$ & 4 & $\begin{array}{l}\text { Single wire shock proof } \\
\text { hammer installation } \\
\text { Split conductor spacer }\end{array}$ \\
\hline 13 & & $\begin{array}{l}\text { Flexible anchor } \\
\text { drill }\end{array}$ & / & 1 & $\begin{array}{l}400 \sim 750 \mathrm{kV} \\
800 \sim 1000 \mathrm{kV}\end{array}$ \\
\hline 14 & & $\begin{array}{c}\text { Tractor cutter } \\
\text { grinding }\end{array}$ & $3 t, 5 t$ & 1 & at all levels \\
\hline
\end{tabular}

Grounding device installation. The grounding patterns in the plain area are mostly horizontal grounding. It is recommended the chain trencher according to general soil, hard soil and other geological conditions. To avoid medicinal herbs, garden, nursery, other economic crops and crossing the road and oil pipeline, it is recommended to use horizontal directional drilling rig. Statistical table of typical equipment for grounding device is shown in Table 7.

Table 7 Statistical table of typical equipment for grounding device

\begin{tabular}{cccccc}
\hline No & $\begin{array}{c}\text { construction } \\
\text { procedure }\end{array}$ & $\begin{array}{c}\text { Construction } \\
\text { equipment }\end{array}$ & Models & number & Scope of application \\
\hline 1 & & Trenching machine & $0.3 \mathrm{~m} 3$ & 1 & at all levels \\
2 & Grounding & alternator & $2 \mathrm{~kW}$ & 2 & at all levels \\
3 & $\begin{array}{c}\text { device } \\
\text { installation }\end{array}$ & $\begin{array}{c}\text { Electric welding } \\
\text { machine } \\
\text { Directional drilling } \\
\text { machine }\end{array}$ & 23kVA & 2 & at all levels \\
4 & & DDX-160 & 1 & at all levels \\
\hline
\end{tabular}

\section{Conclusion}

(1) Through investigation and analysis of domestic and international current status about construction industry construction equipment configuration, we clear that construction equipment need to be scientific allocated according to the procedure in the mode of the whole process of mechanization construction in lines, in which we should consider the equipment applicable scope, the plain area terrain, construction process and the project scale.

(2) The whole mechanical construction of overhead transmission lines has seven processes, including temporary road constr uction, material transportation, excavation concrete pouring, tower 
group, guide wire erection and ground laying. According to different processes, the typical construction equipment configuration for each working procedure in the plain area is put forward.

\section{Acknowledgement}

This research was financially supported by the Science and Technology Project of China State Grid Corp. The number of the project is GC71-15-042.

\section{Reference}

[1] Tao LIU. Equipment Management of Mechanized Construction[J]. Equipment Management \& Maintenance Technology, 2008, 25(3): 78-80. In Chinese

[2] Xian-Gao TANG, Xiang-Hua SHAN, Zhi-Hong WEI, etc. Economic Analysis on Mechanical Matching in Construction of Long Railway Tunnels [J]. Tunnel Construction, 2012, 32(3): 270-274. In Chinese

[3] Jun-Bo FANG, Jia-Yi HUANG, Kai-Rong HONG, et al. Study on mechanical matching and equipment for long tunnel construction [J]. Highspeed Railway Technology, 2011(s): 17-22. In Chinese

[4] Wei ZHANG, Jian-Min CHEN, Ming-Liang JIN, Deng-Cheng MA, Ru-Cun XU, et al. Economy Research on Mechanized Construction of Tunnel with Dual-arm Jumbo[J]. Road Machinery \& Construction Mechanization, 2015, 32(6): 99-102. In Chinese

[5] Jian-Hua CAI. Analysis of the influence and Control of Expressway Bituminous Pavement Flatness by Mechanized Construction[J]. Construction Quality, 2014(10): 55-56. In Chinese 